\title{
BASIC OPTIONS IN THE NON-IMMIGRANT BUSINESS CONTEXT
}

\author{
Jeff Papa*
}

\section{INTRODUCTION}

Companies located in the United States are sometimes confronted with a lack of qualified American applicants for a given position. While the goal of policy and individual employers should always be to fill these positions with American workers, this is often not possible or practical. If such a company is unable to locate a qualified U.S. worker, the company may turn to foreign graduates of U.S. universities or accept applications from qualified professionals trained in other countries.

The process of obtaining permission for these individuals to work in the United States on a temporary basis can often be confusing because there are many categories of work authorization, and the rules often change. Additionally, a given individual may qualify for more than one type of authorization (in which case the most advantageous or appropriate route should be determined), or the individual may not qualify for any category of authorization. This Article will explain the basic categories available in these circumstances, as well as various other related considerations that must be analyzed in the non-immigrant status context. For students or beginning practitioners, this Article may provide some useful insight into the terminology, inter-working of agencies, and context of available non-immigrant options.

\section{REORGANIZATION OF LEGACY INS}

As part of the response to the terrorist events on 9/11, the Department of Homeland Security (DHS) was created and several existing agencies were reorganized, split apart, combined, or eliminated. One of these agencies was the U.S. Immigration and Naturalization Service (INS).

Legacy INS functions were split into enforcement, benefits, and border components. Prior to the split, the INS was a part of the U.S. Department of Justice. Legacy INS functions, responsible for the granting of benefits, were located in a new entity, now known as the U.S. Citizenship and Immigration Services (CIS) and located in the new DHS. The enforcement functions of legacy INS were located in a new entity known as the U.S. Immigration and Customs Enforcement (ICE).' The Legacy INS border processing and

* Immigration and Governmental Services Attorney, Barnes \& Thornburg, LLP. B.S., Rose-Hulman Institute of Technology; M.A., Ball State University; J.D., Indiana University School of Law-Indianapolis.

1. Homeland Security Act of 2002, Pub. L. No. 107-296, 116 Stat. 2135 (2002). 
protecting functions were combined with elements of the former U.S. Customs Service (formerly part of the Treasury Department), and U.S. Border Patrol, and placed in the new entity known as the U.S. Customs and Border Protection (CBP), also as a part of the newly-formed DHS. ${ }^{2}$

As the U.S. Department of Labor (DOL) and the U.S. Department of State (DOS) continue to be involved in various aspects of immigration law, individuals dealing with immigration on a daily basis must now consider the rules and processes of at least five agencies when taking any immigrationrelated action, including DOL, DOS, ICE, CBP, and CIS. Basically, the CIS reviews, investigates and approves new, changed, or extended status for aliens wishing to be in the United States on a temporary or long-term basis. The CBP processes and investigates these individuals when they present themselves at a U.S. air, land, or sea port for entry. CBP also handles the former customs duties and processes returning U.S. citizens and permanent residents. ${ }^{3}$ The DOS is responsible for verifying that an individual has the claimed identity, authorization, or qualification, as well as appropriate documentation, and is also responsible for issuing visas to qualified individuals. ${ }^{4}$ The ICE investigates individuals and organizations that violate immigration rules inside the United States, and it apprehends and removes or prosecutes unauthorized or criminal aliens. ${ }^{5}$ Finally, the DOL is involved in certain aspects of immigration applications to ensure protection of American workers from unfair competition and unfairly low wages. ${ }^{6}$

\section{STATUS VERSUS VISA}

When discussing non-immigrant classifications, it is easy to confuse the concepts of status and visa. In common parlance, many people refer to the authorization for a foreign individual to be present or to work in the United States as a "visa." This usage is incorrect, and should be replaced with the term "status." A visa can be thought of as an entry document needed to enter the United States at an airport, land border post, or seaport, ${ }^{7}$ while status is the underlying permission to be in or work in the United States. ${ }^{8}$

2. 8 C.F.R. $\S 100.4$ (2004).

3. See generally 8 C.F.R. $\S \S 236,238-240$ (2004) (discussing expedited removal, removal of aggravated felons, removal of aliens); 28 C.F.R. $\S 200$ (2004); Department of Homeland Security Reorganization Plan of Nov. 25, 2002, pursuant to Homeland Security Act of 2002, Pub. L. No. 107-296, 116 Stat. 2135 (2002), http://www.dhs.gov/interweb/assetlibrary/ reorganization_plan.pdf (last visited Jan. 13, 2005).

4. 22 C.F.R. $\$ \S 22,40,41,42,44,53,62$ (2004).

5. See sources cited supra note 3 .

6. 20 C.F.R. $\S \S 655-56(2004)$.

7. 22 C.F.R. $\$ 41(2004)$.

8. See 8 C.F.R. $\S \S 205,212,214,248$ (2004); Immigration and Nationality Act $\S$ 214(c)(1), 8 U.S.C. § 1184(c)(1) (2004). 
In most cases, status is granted by the CIS. This means that the CIS has authorized an individual to be present, or to work in the United States. ${ }^{9}$ If the individual is already present in the United States in a status that allows for change to another status, the authorization from CIS converts the person's status, and that individual may take up activity in accordance with the new status on its effective date. ${ }^{10}$ Additionally, an individual in the United States who receives an extension of his or her current status may remain in the United States for the duration of the extension without the need for a visa. ${ }^{11}$

A visa, on the other hand, is a document that allows an individual to enter the United States. ${ }^{12}$ Unlike status, which is approved by the CIS, visas are issued by the DOS. ${ }^{13}$ In other words, a person already present in the United States who has been authorized by the CIS to change status or to extend their current status would not need a visa unless travel out of the United States is planned. Authorization from the CIS grants that person status to remain and act in accordance with that new or extended status. ${ }^{14}$

If, however, CIS approves a status for a person outside the United States, that person must present the status approval to a U.S. Consulate abroad (normally in his or her home country) in order to obtain a visa prior to entering the United States. ${ }^{15}$ This also applies to persons who obtain an approval but are not eligible to change status in the United States, and to those with a legal status in the United States who decide to travel out of the United States but do not currently have a valid visa for reentering the United States; such individuals must also obtain a visa before returning to the United States ${ }^{16}$ Also, it is important to note that not only does a visa need to be current (not expired) for entry into the United States, but it must be in the same category as the status approved by the CIS as well. ${ }^{17}$

Some examples of individuals who would need to obtain a new visa include persons abroad who will enter the United States to take up a new status, and individuals currently present in the United States who travel out of the

9. See 8 C.F.R. $\S \S 205,212,214,248$; Immigration and Nationality Act $\S 214(c)(1), 8$ U.S.C. $\$ 1184(c)(1)$.

10. See Immigration and Nationality Act $\S 248,8$ U.S.C. $\S 1258$ (2004) (amended by $\S$ 301(b)(2) of the Illegal Immigration Reform and Immigrant Responsibility Act of 1996 (IIRIRA)).

11. See 8 C.F.R. $\$ \S 214.1,248$ (2004).

12. See 22 C.F.R. $\$ 41 ; 8$ C.F.R. $\$ 212.1$ (2004).

13. See 22 C.F.R. $\$ 41 ; 8$ C.F.R. $\$ 212.1$.

14. See 8 C.F.R. $\$ 214$ (2004).

15. 22 C.F.R. $\$ 41.10$.

16. Id. $\S 41.1-41.3$.

17. Id. $\$ 41.112$ (d). One exception is the thirty-day rule, which allows individuals to travel to, and return from, a contiguous territory (such as Canada and Mexico) if the trip is less than thirty days in length, the individual has a current passport and an unexpired I-94 card, does not apply for a new U.S. visa while abroad, and is not a citizen of a state sponsor of terror. F and $\mathbf{J}$ status holders may also use this rule to visit adjacent islands (such as those in the Caribbean). Id. 
United States holding an expired visa, a visa of a different category than the current status, and those persons not eligible to change status within the United States. A notable exception to these entry rules is that Canadian citizens are exempt from the need for a visa in many non-immigrant categories. ${ }^{18} \mathrm{~A}$ Canadian citizen with status approval in most non-immigrant categories may simply present a current Canadian passport or long-form birth certificate along with the status-authorizing document to gain admission to the United States. ${ }^{19}$

\section{NON-IMMIGRANT VERSUS IMMIGRANT}

Immigration law is generally divided into two broad categories of aliens seeking to enter the United States. These categories are Non-Immigrant and Immigrant. Aliens seeking to enter and remain indefinitely in the United States are classified as persons with immigrant intent, and they must seek an appropriate status in an immigrant classification. Aliens applying for temporary status in the United States normally must seek a non-immigrant classification. ${ }^{20}$

Successful immigrant applicants receive Lawful Permanent Resident Status. $^{21}$ This allows an individual to remain and work in the United States indefinitely, as long as they maintain a U.S. residence and avoid legal trouble. ${ }^{22}$ This status is commonly referred to as a "Green Card," although the card is not in fact green. ${ }^{23}$ Immigrant classifications are more difficult to obtain, and normally involve much more extensive qualification and proof, as well as medical and additional background checks. Non-immigrant classifications also go through qualification and background checking, but are more readily available to more individuals than immigrant classifications.

U.S. immigration law assumes that all individuals have immigrant intent, and persons applying for a non-immigrant classification must overcome this assumption or they are denied most non-immigrant classifications (excluding $\mathrm{E}$, for example). ${ }^{24}$ This is an important consideration, because in many cases applicants for non-immigrant status or visas need to document strong ties to their home country and demonstrate no current intention to stay beyond a temporary authorization. ${ }^{25}$

18. Id. $\S 41.2$. However, Canadians need visas for the $\mathrm{E}$ and $\mathrm{K}$ classifications. Id. $\S$ 41.2(m).

19. 8 C.F.R. $\$ 212.1($ a).

20. See U. S. DePartment OF State, 9 Foreign AfFairs MANUAL, Visas 41.53-41.57 (2003), http://foia.state.gov/REGS/fams.asp?level=2\&id=10\&fam $=0$ (last visited Feb. 7, 2005).

21. See 8 C.F.R. $\$ \S 204,211,247$ (2004).

22. Id.

23. See Why Isn't The Green Card Green?, at http://uscis.gov/graphics/aboutus/history/ articles/green.htm for a discussion on the history of green cards (last visited Nov. 29, 2004).

24. Immigration and Nationality Act $\$ 214(\mathrm{~b}), 8$ U.S.C. $\S 1184(\mathrm{~b})$. An exception to this is the "dual-intent" rule, which allows for individuals applying for $\mathrm{H}$ or $\mathrm{L}$ non-immigrant status to concurrentiy hold immigrant intent. 8 C.F.R. $§ 214.2(\mathrm{~h})(16)(1)(16) ; 70$ INTERPRETER RELEASES 1456-58 (Nov. 1, 1993).

25. See Immigration and Nationality Act $\S \S 101(a)(15)(\mathrm{F})(1), 101(\mathrm{a})(15)(\mathrm{H})(\mathrm{ii})(\mathrm{a})$, 


\section{SELECTED NON-IMMIGRANT CLASSIFICATIONS AND RELATED ISSUES}

In the non-immigrant commercial context, there are many considerations to examine in order to determine if an employer may apply to the CIS for nonimmigrant status on behalf of a potential employee. These considerations usually involve both the alien showing qualification for a given status, as well as the employer demonstrating that a position qualifies as eligible to be filled by a classification of non-immigrant.

The most common non-immigrant classifications are set out below. While the various common categories are described, each category has an almost unlimited set of special exceptions and circumstances that can affect eligibility, duration, travel requirements and other facets of an individual circumstance. These examples are intended for general knowledge; actual cases should be examined by an immigration attorney or other individual with appropriate expertise.

\section{A. HIB Status}

The H1B classification is available to alien professionals who will fill a specialized knowledge position in the United States. Basic eligibility for H1B status requires that the proffered job requires at least a bachelor's degree in a specialty subject to properly perform the duties, and that the individual who will fill the position has that required education. ${ }^{26}$ An example, here would be a proffered position of mechanical engineer. An employer would have to demonstrate that this position mostly involves performing duties normally associated with a mechanical engineer, and the potential employee would be required to demonstrate that he or she has earned at least a bachelor's degree in mechanical engineering or a closely-related subject.

More specifically, the position must meet one of four categories in order to qualify for H1B classification. One of the following criteria must be demonstrated: a bachelor's degree or equivalent is normally the minimum requirement for entry into the particular position; such degree requirement is common in the industry in parallel positions among similar organizations or that the particular position is so complex or unique that a degree is required; the employer normally requires such a degree or equivalent; or the nature of the specific duties is so specialized and complex that knowledge required to perform the duties is usually associated with attainment of a degree. ${ }^{27}$

In order to obtain CIS approval for an individual's H1B status, the company also must demonstrate proof of the prevailing wage for the offered position in the metropolitan area in which it will be located, and attest that the employee will be paid a minimum of ninety-five percent of that prevailing wage (some fields require a minimum salary equal to or greater than 100 percent of 
the prevailing wage) during the course of H1B employment. ${ }^{28}$ Furthermore, H1B approvals granted by the CIS are employer and location-specific. An alien with an H1B approval may not move to a new work location or different employer without first applying for a new or amended H1B approval from the CIS. Additionally, an employer who terminates an H1B employee prior to the end of the authorized period of employment is responsible for providing reasonable transportation home. ${ }^{29}$

Companies may file an initial petition for an H1B employee with any requested length of validity up to three years. An individual may request extensions of H1B status through a maximum time of six years, after which the individual is required to depart the United States for a period of at least one year before again being eligible for H1B status. ${ }^{30}$ Time spent in $\mathrm{L}$ status by an individual also counts against this six year maximum. ${ }^{31}$

Spouses and unmarried children under the age of twenty-one may apply to accompany an individual holding $\mathrm{H} 1 \mathrm{~B}$ status as $\mathrm{H} 4$ dependents. $\mathrm{H} 4$ status allows immediate family members to accompany an H1B temporary worker, but $\mathrm{H} 4$ holders may not work in the United States. ${ }^{32}$

The number of new H1B approvals that may be granted each year is limited to $65,000 .^{33}$ During the 1990 s, Congress repeatedly increased this number to 195,000 , but beginning with fiscal year 2004 Congress did not act to increase the number, and the cap on new H1B petitions fell back to 65,000 for each succeeding fiscal year. Of these 65,000 potential H1B slots, 6,800 are reserved each year for nationals of Chile and Singapore under recent free-trade agreements. ${ }^{34}$ Universities, some federal agencies, some non-profit research institutions, and some individuals who are current or recent H1B status-holders

28. $I d . \S 214.2(\mathrm{~h})(4)(\mathrm{i})(\mathrm{B})(1)$.

29. Id. $\S 214.2(\mathrm{~h})(4)(\mathrm{iii})(\mathrm{E})$. This is usually considered to be a one-way, coach-class airline ticket to the individual's home country.

30. Individuals in H1B status who have a labor certification request filed on their behalf at least one year prior to the exhaustion of the six-year maximum may petition annually for an unlimited number of one year extensions until the labor certification request is adjudicated. American Competitiveness in the Twenty-First Century Act of 2000 \$ 106(a), Pub. L. No. 106313, 114 Stat. 1251 (2000).

31. 8 C.F.R. $\$ 214.2(\mathrm{a})(\mathrm{h})(13)(\mathrm{iii})$

32. Most non-immigrant classifications allow for spouses and unmarried children under the age of twenty-one to obtain a dependent-based non-immigrant visa in order to accompany a principal applicant. This can present a problem where the significant other is not legally married to the principal applicant. Non-married co-habiting partners can be admitted as B2 visitors to accompany non-immigrants where a dependent status would not technically be available. State Dept. Cable No. 01-118790 (July 9, 2001), reprinted in 78 INTERPRETER RELEASES 1175-77 (July 16, 2001).

33. Immigration and Nationality Act $\S 214(\mathrm{~g})(1)(A), 8$ U.S.C. $\S 1184(\mathrm{~g}) ; 8$ C.F.R. $\S$ 214.2(h)(8)(i)(B).

34. U.S.-Chile Free Trade Agreement Implementation Act, Pub. L. No. 108-77, 117 Stat. 909 (2003); U.S.-Singapore Free Trade Agreement Implementation Act, Pub. L. No. 108-78, 117 Stat. 948 (2003). U. S. DEParTMENT OF STATE, 9 Foreign Affairs Manual, Visas 41.53 (2003), http://foia.state.gov/masterdocs/09fam/0941053R.pdf (last visited Feb. 7, 2005). 
are exempt from the cap and may submit new H1B approvals outside the 65,000 limit. $^{35}$

The 65,000 available H1B slots do not meet the current need for H1B employees, as evidenced by the fact that for fiscal year 2004 (October 1, 2003 through September 30, 2004), all of the H1B slots were filled (and thus no new applications accepted) by February, 2004. ${ }^{36}$ The demand in fiscal year 2005 was even greater as the CIS closed new applications on the very first day of the fiscal year, October $1,2004 .^{37}$ As a consequence, no new applications for nonexempt H1B positions may be filed for a starting date earlier than October 1, 2005. U.S. employers will go almost a full calendar year without available H1B slots, unless Congress acts to make additional numbers available.

In late 2004, Congress passed several significant changes to the H1B program. Congress reinstated and made permanent the required worker training fee to be paid for each H1B applicant. This fee is $\$ 1,500$ for employers with more than twenty-five employees, and $\$ 750$ for employers with twenty-five or fewer employees. ${ }^{38}$ Congress also removed the provision allowing employers to pay as low as ninety-five percent of the prevailing wage-all employers must now pay at least 100 percent of the prevailing wage and the existing two levels of wages are changed to four levels of wages. ${ }^{39}$ In light of the shortage of H1B slots available, Congress created a new annual allotment of 20,000 additional H1B slots, which will be available only to aliens who have earned a masters degree or higher at a U.S. institution of higher education. ${ }^{40}$ A $\$ 500$ fraud fee has also been added to all $\mathrm{H} 1 \mathrm{~B}$ petitions to assist the CIS in discovering and dealing with fraud. ${ }^{41}$

35. Information Regarding the H-1B Numerical Limitation for Fiscal Year 2000, 65 Fed. Reg. 15178-80 (Mar. 21, 2000); Information Regarding the H-1B Numerical Limitation for Fiscal Year 2004, 69 Fed. Reg. 8675 (Feb. 25, 2004); 78 INTERPRETER RELEASES 1108-17 (July 2, 2001).

36. Press Release, American Immigration Lawyers Association, H-1B Cap Reached Signals Changes Needed, Posted on AILA InfoNet at Doc. No. 04021711 (Feb. 17, 2004), at http://www.aila.org/contentViewer.aspx?bc=9,594,4717 (last visited Mar. 6, 2005).

37. See Press Release, U.S. Department of Homeland Security, U.S. Citizenship and Immigration Services, Members of the Professions holding Advanced Degrees or Aliens of Exceptional Ability, § 203(b)(2) of the Act (Oct. 1, 2004), available at http://www.uscis.gov/ graphics/ lawsregs/admindec3/b5/index.htm (last visited Nov. 6, 2004).

38. Consolidated Appropriations Act, 2004, Pub. L. No. 108-447, § 422, 118 Stat. 2809 (2004).

39. Id. § 423.

40. Id. $\S 425$. Interestingly, although Congress specifically authorized the availability of these additional 20,000 H1B slots beginning in early March, the CIS issued a press release on March 4, 2005 stating that practitioners may not yet file for these slots because the CIS has failed to promulgate regulations for the technical implementation of the program. See Press Release, U.S. Department of Homeland Security, U.S. Citizenship and Immigration Services, USCIS to Implement H-1B Visa Reform Act of 2004 (Mar. 4, 2005), at http://uscis.gov/graphics/ publicaffairs/newsrels/H1BVisaReformAct03_04_05.pdf (last visited Mar. 6, 2005).

41. Consolidated Appropriations Act, 2004, Pub. L. No. 108-447, § 426, 118 Stat. 2809 


\section{B. Ll Status}

Companies with operations in both the United States and foreign countries may be eligible to utilize the $\mathrm{L} 1$ status option. ${ }^{42}$ To qualify for $\mathrm{L}$ status, an individual must normally have worked for at least one year of the past three years as a specialized knowledge or managerial/executive employee of a company abroad. ${ }^{43}$ If that company abroad shares common ownership and control with a U.S. parent, subsidiary, or sister company, the U.S. company may petition the CIS to bring that individual temporarily to the United States in L status.

Two types of L1 status are available: L1A and L1B. L1A status is available to an individual who will be filling a managerial or executive role at the U.S. operation. Individuals in L1A status are limited to a total period, including extensions, of seven years in this status. ${ }^{44}$ L1B status is available to individuals who will fill a specialized knowledge role at the U.S. operation. Individuals in L1B status are normally limited to a total period, including extensions, of five years in this status. ${ }^{45}$ In some limited circumstances, an employee moved to a managerial or executive role with more than one year of L1B eligibility remaining may apply for a change to L1A status, and therefore be subject to the longer seven year limit on stay. ${ }^{46}$

Recognizing the need for flexibility, the law allows for classification as L1B or L1A to depend on the actual duties of the position in the United States, regardless of the duties abroad. In other words, a qualifying specialized knowledge employee abroad could qualify as a managerial employee, L1 A, if the U.S. duties qualify as managerial or executive, and a manager or executive with the operation abroad could qualify as an L1B, specialized knowledge employee, if the U.S. position involves the use of special knowledge rather than managerial or executive functions. ${ }^{47}$

Spouses and unmarried children under the age of twenty-one may apply to accompany an individual holding L1B or L1A status as L2 dependents. Children in L2 status may not work in the United States. However, L2 spouses may apply separately for work authorization based on status as an L2 spouse. ${ }^{48}$

Established companies who have demonstrated qualification are also eligible to apply for a blanket authorization from the CIS, if they meet certain requirements. ${ }^{49}$ A company may qualify for blanket approval if it has at least

(2004).

42. 8 C.F.R. $\$ 214.2(1)$.

43. Id. $\$ 214.2(1)(1)(\mathrm{i})$.

44. Immigration and Nationality Act $\S 214(\mathrm{c})(2)(\mathrm{D})(\mathrm{i}), 8$ U.S.C. $\S 1184(\mathrm{c})$; see Immigration and Nationality Act $\S 101(\mathrm{a})(15)(\mathrm{L})$ for limitation on managerial or executive capacity.

45. Immigration and Nationality Act $\S 214(c)(2)(D)(i i), 8$ U.S.C. $\S 1184(c)$.

46. 8 C.F.R. $\S 214.2(1)(15)(i i)$.

47. Matter of Vaillancourt, 13 I. \& N. Dec. 654 (R.C. 1970).

48. Immigration and Nationality Act $\S 214(\mathrm{c})(2)(\mathrm{E}), 8$ U.S.C. $\S 1184(\mathrm{c})$.

49. 8 C.F.R. $\$ 214.2(1)(7)(i)$. 
three domestic and foreign branches, and the company has either transferred ten employees in L1 status in the past year, or has $\$ 25$ million in U.S. sales or employs at least 1,000 workers in the United States. ${ }^{50}$

In the blanket approval process, the CIS examines the company's status, qualifications, and claims. If the CIS finds the company meets all of the requirements, the CIS may issue a blanket $L$ approval notice. This notice may then be used by intra-company transferees to apply directly at a U.S. consulate abroad without gaining individual approval from the CIS in each case. ${ }^{51}$ The consulate then has the responsibility to verify the individual's identity, as well as to verify that the individual meets all of the education, experience, and timewith-company requirements for $\mathrm{L}$ classification. ${ }^{52}$

One exception to the blanket process is that individuals who do not possess at least a related bachelor's degree may not utilize the blanket process to obtain L1B status. ${ }^{53}$ Benefits to the company of utilizing this pre-screening process include eliminating the need to wait for individual approval from the CIS, and also that the blanket process allows individuals with as little as six months of service to the foreign parent, subsidiary, or sister company to qualify for L status. ${ }^{54}$

In late 2004, Congress passed several significant changes to the $\mathrm{L}$ program. L employees are now prohibited from being primarily stationed at the worksite of a third party where the employee would be supervised and controlled by a third party or where the placement is simply an arrangement to provide labor to the third party. ${ }^{55}$ Congress also eliminated the six month provision for blanket $L$ applicants —all L employees must now have a minimum of one year of service to the overseas affiliate. ${ }^{56}$

\section{TN Status}

TN status is a special classification created to comply with NAFTA, and is currently available to Canadian and Mexican nationals. ${ }^{57}$ However, additional restrictions imposed on Mexican nationals make this classification more difficult to obtain. ${ }^{58} \mathrm{TN}$ status can be obtained by applying to the CIS for

50. Id. § $214.2(\mathrm{l})(4)$.

51. Id. $\S 214.2(1)(5)(\mathrm{ii})$.

52. Id.

53. Id. § 214.2(1)(5)(ii)(D).

54. Immigration and Nationality Act $\S 214(c)(2)(A), 8$ U.S.C. $\S 1184(c)(2)(A)$. Utilization of this six month provision must be carefully examined, though, as it may negatively impact the ability of the intra-company transferee to obtain permanent residence. 8 U.S.C. $\S$ 1184.

55. Consolidated Appropriations Act, 2004, Pub. L. No. 108-447, § 412, 118 Stat. 2809 (2004).

56. Id. $\S 413$.

57. 8 C.F.R. $\S 214.6$.

58. See, e.g., 8 C.F.R. $\S 214.6(\mathrm{~d})$. 
advance permission or extensions of status. ${ }^{59}$ However, in most cases an initial Canadian TN applicant may proceed directly to an airport, land border, or seaport for TN processing by CBP personnel. Mexican nationals may now apply directly to a U.S. consulate for TN status. ${ }^{60}$

TN status is limited to professionals in certain defined professions. ${ }^{61}$ In most cases it must be demonstrated that the position being offered is a professional position that is specifically listed in the NAFTA agreement. ${ }^{62}$ Most of the professional categories require that an individual possess at least a related bachelor's degree in order to qualify for TN status. One exception is the position of management consultant, which alternatively requires at least five years of related experience and is limited to temporary consulting (it may not be used to fill a regular position).

TN status is limited to an initial approval of one year, but may be extended in one year increments an unlimited number of times. However, TN status does not allow for immigrant intent, and CBP or CIS officers may deny an extension if immigrant intent is detected. ${ }^{63}$ Some categories, such as management consultant, by their very nature do not justify excessive extensions.

Spouses and unmarried children under the age of twenty-one may apply to accompany an individual holding TN status as TD dependents. TD dependents may not work in the United States. ${ }^{64}$

\section{E Status}

Individuals who are nationals of countries with which the United States has a treaty of commerce and navigation, or a bilateral investment treaty, may be eligible for E status. ${ }^{65}$ Initially, E-status holders are admitted for a period of two years, which can be extended indefinitely. ${ }^{66}$

There are two types of E status. E1 status is for aliens conducting trade in the United States, and E2 status is for aliens overseeing investment in the

59. Id. $\S 214.6(\mathrm{~h})(2)$.

60. ld. $\S 214.6(\mathrm{~d})$.

61. Id. $\S 214.6(\mathrm{j})$. Designated professions include: Accountant, Architect, Computer Systems Analyst, Disaster Relief Insurance Claims Analyst, Economist, Engineer, Forester, Graphic Designer, Hotel Manager, Industrial Designer, Interior Designer, Land Surveyor, Landscape Architect, Lawyer, Librarian, Management Consultant, Mathematician, Range Manager, Research Assistant, Scientific Technician/Technologist, Social Worker, Sylviculturist, Technical Publications Writer, Urban Planner, Vocational Counselor, Medical/Allied Professional (Dentist, Dietician, Medical Laboratory Technologist, Nutritionist, Occupational Therapist, Pharmacist, Physician, Physical Therapist, Psychologist, Recreational Therapist, Registered Nurse, Veterinarian), Scientist, and Teacher. Id. $\$ 214.6(\mathrm{c})$.

62. Id. § 214.6(c).

63. 22 C.F.R. $\$ 41.59(\mathrm{c})$.

64. 8 C.F.R. $\& 214.6(j)$.

65. Id. $\S 214.2(\mathrm{e}), \S 214.2(\mathrm{R})(6)$.

66. Id. $\S 214.2(\mathrm{e})(19)-(20)$. 
United States. ${ }^{67}$ An individual seeking E status must be a national of a country with such a treaty, and the company the individual is representing must be owned or controlled by a majority of nationals of that country.

As $\mathrm{E}$ status is conditioned on the existence of a relevant treaty between the United States and the national's foreign government, application for initial E status may be made at a U.S. consulate in the foreign national's home country. This allows each U.S. consulate located in a country with an appropriate treaty to become familiar with the existence and terms of such treaty, and to better adjudicate E status applications relevant to the appropriate treaty. Alternatively, an E petition may be filed at a designated CIS service center. $^{68}$

Spouses and unmarried children under the age of twenty-one may apply to accompany an individual holding $\mathrm{E}$ status as $\mathrm{E}$ dependents. ${ }^{69}$ Children in $\mathrm{E}$ status may not work in the United States. However, E spouses may apply separately for work authorization based on status as an E spouse. ${ }^{70}$

\section{E. B Status}

Individuals may also apply for B visitor status. ${ }^{71}$ There are two types of B status. B1 status is for business visitors, while the B2 status is intended for pleasure visitors, such as for tourism, personal visits, and medical care. B status can also be obtained directly from a U.S. consulate without prior approval from CIS. ${ }^{72}$

Visitors in B status may not be gainfully employed during their stay in the United States. ${ }^{73}$ A visitor admitted in B 1 status may attend business meetings, conduct negotiations, offer technical advice, and conduct other short-term business functions, but may not engage in regular labor or fill an open position in any way. ${ }^{74}$

The B classification does not allow derivative family members to obtain status under the principal applicant. Each individual desiring to visit the United States in B status must obtain separate authorization. While a B status visitor may be granted up to one year on entry, normal procedure allows for a sixmonth entry. ${ }^{75}$ Admission is usually granted for the period necessary to

67. Immigration and Nationality Act $\S 101(\mathrm{a})(15)(\mathrm{E})(\mathrm{i})$ and (ii), 8 U.S.C. $\S$ $1101(\mathrm{a})(15)(\mathrm{E})(\mathrm{i})$ and (ii).

68. 8 C.F.R. $\$ 214.2($ e)(8)(iii). However, when exiting the United States a new visa may be required in order to return, and the U.S. consulate is likely to re-adjudicate eligibility prior to issuing an E category visa for U.S. reentry.

69. Id. \& $214.2(\mathrm{e})(4)$.

70. Immigration and Nationality Act $\S 214(\mathrm{e})(6), 8$ U.S.C. $\S 1184(\mathrm{e})(6)$.

71. Id. $\S 101(\mathrm{a})(15)(\mathrm{B}), 8$ U.S.C. $\S 1101(\mathrm{~A})(15)(\mathrm{B})$.

72. U. S. DEPARTMENT OF STATE, 9 Foreign AFFaIRS MANUAL, VISAS 41.31 (2004), nn. 411, http://foia.state.gov/masterdocs/09fam/0941031N.pdf (last visited Feb. 7, 2005).

73. 8 C.F.R. $\S 214.1$ (e).

74. 22 C.F.R. $\$ 41.31$ (b)(1)-(2).

75. 8 C.F.R. $\S 214.2($ b)(1). 
accomplish the objectives presented, and justified by the individual when presenting themselves to a CBP officer. If circumstances indicate a shorter period of stay is warranted, the CBP officer may authorize a period of less than six months, or in extreme cases, a period of longer than six months (but not more than one year). Limited extensions of B status may be obtained by applying directly to the CIS. ${ }^{76}$

\section{F. Visa Waiver}

Individuals holding passports from certain countries with low immigration fraud rates are eligible to utilize the Visa Waiver Program in place of visitor status. The visa waiver program allows these individuals to present themselves to a CBP officer at a U.S. point of entry using only a qualifying passport, without the need to apply first for CIS approval or a consular visa. ${ }^{77}$

Individuals entering the United States on the Visa Waiver Program are granted an admission period of ninety days, during which time they may not work. This period may not be extended, and the individual may not change to a different non-immigrant classification without departing the United States. In some limited circumstances, a U.S. citizen's immediate family member may be able to file an immigrant petition allowing the individual to remain in the United States. ${ }^{78}$

The visa waiver program has come under enhanced restrictions since 9/11. Starting on September 30, 2004, all visitors entering the United States on visa waiver became part of the "U.S. Visit" program. They are photographed, fingerprinted, and have their entry as well as departure dates monitored. The "U.S. Visit" program was previously in effect for those who do not qualify for the visa waiver program. As of October 26, 2004, all passports used for visa waiver admissions must be machine readable or the passport holder will require a visa for entry. The October 26,2004 , deadline for all visa waiver applicants to present passports containing biometric identification information at ports of entry into the United States has been extended until October 26, 2005. ${ }^{79}$

\section{G. J Status}

The $\mathbf{J}$ classification allows for individuals to participate in approved exchange visitor programs within the United States. This category is limited to certain types of professionals, students, teachers, trainees, and scholars. ${ }^{80}$ The duration of the $\mathbf{J}$ status varies depending on the planned activity.

76. Id. § 214.2(b)(2).

77. Id. $\S 217.1(2004)$.

78. Id. \$245.1(i) (2004).

79. See Press Release, U.S. Dept. of State, Bureau of Public Affairs, Extension of Requirement for Biometric Passport Issuance by Visa Waiver Program Countries (Oct. 10, 2004), at http://www.state.gov/r/pa/prs/ps/2004/35066.htm (last visited Feb. 7, 2005).

80. Immigration and Nationality Act $\S 101(a)(15)(J), 8$ U.S.C. $\S 1101(a)(15)(J)$. 
$\mathrm{J}$ status requires the individual to be participating in a program approved by DOS as an appropriate J program. ${ }^{81}$ Participation in many $\mathrm{J}$ programs will result in a two year home residency requirement for the participants. Under certain circumstances, such as if the individual receives funding from the United States or a foreign government, or if the skills used or learned in the $J$ program are listed by DOS as being needed in the individual's home country, the individual may be required to return to his or her home country for a minimum of two years before any further immigrant or non-immigrant status can be awarded to the alien. ${ }^{82}$ In certain circumstances, the alien may apply for a waiver of this requirement. ${ }^{83}$

$\mathrm{J}$ Status allows for spouses and unmarried children under the age of twenty-one to accompany the $\mathrm{J} 1$ status holder as $\mathrm{J} 2$ dependents. $\mathrm{J} 2$ dependents may apply to the CIS for work authorization to support themselves, but not to support the $\mathrm{J} 1$ principal. ${ }^{84}$

\section{H. H3 Status}

The H3 classification is available to bring trainees to the United States under certain circumstances. Gaining $\mathrm{H} 3$ approval for an individual from the CIS requires very detailed information about both the individual and the training program. ${ }^{85}$

H3 trainees cannot be used for productive work while in the United States, unless such work is incidental to the training program. The training that is being provided should be unavailable in the alien's home country. The company or organization sponsoring the $\mathrm{H} 3$ trainee cannot have the intention of eventually employing the trainee in the United States. The training program should already exist and be fully planned, including schedule and testing details. It should be demonstrated that the alien has a need for the training, beyond simple improvement on existing skills. ${ }^{86}$

$\mathrm{H} 3$ status allows a maximum program length of two years, but in any case the time requested must be justified by a detailed training and evaluation plan. ${ }^{87}$ Spouses and unmarried children under the age of twenty-one may apply for $\mathrm{H} 4$ status to accompany an $\mathrm{H} 3$ trainee. $\mathrm{H} 4$ dependents are not authorized to work in the United States.

81. 22 C.F.R. $\S 62.20$ (2004).

82. Id. $\S 41.63$.

83. Id. $\S 41.63(\mathrm{~b})$.

84. 8 C.F.R. $\$ 214.2(j)(1)(v)$.

85. Id. $\S 214.2(\mathrm{~h})(7)$.

86. $l$ d. $\& 214.2(\mathrm{~h})(7)(\mathrm{ii})(\mathrm{A})$.

87. Id. $\S 214.2(\mathrm{~h})(9)(\mathrm{iii})(\mathrm{D})(2)$. 


\section{F Status}

F status is accorded to aliens in order to attend school in the United States. F status should only be used by those with the legitimate intent of attending classes and completing an approved program of study. ${ }^{88}$ However, for those individuals in valid student status, some work authorization is possible.

During enrollment in studies, a university may authorize curricular practical training (CPT), which allows off-campus employment in a field related to the student's studies. ${ }^{89} \mathrm{CPT}$ also requires that the work be affiliated with course work through the university. Upon completion of studies, a student may apply for Optional Practical Training (OPT), which allows up to one year of work in a field related to the studies just completed. ${ }^{90}$ Graduates can use this OPT experience to gain practical experience prior to returning home, or they can use the OPT time to begin working prior to applying for a status of longer duration, such as H1B.

\section{J. O Status}

O status is available for aliens who possess extraordinary ability in the sciences, arts, education, athletics, or business, and for support personnel and family members of extraordinary ability aliens. Aliens possessing extraordinary ability are classified as $\mathrm{O}-1,{ }^{91}$ while supporting personnel are classified as $\mathrm{O}$ $2{ }^{92}$ Spouses and unmarried children under the age of twenty-one receive the O-3 classification. ${ }^{93}$ O-3 aliens are not permitted to work in the United States.

\section{K. P Status}

The P1 category is available for entertainers and athletes, as well as support personnel. ${ }^{94}$ P-2 status can be afforded to athletes and entertainers engaged in a reciprocal exchange agreement. P3 status can be obtained for artists and entertainers who enter the United States solely to participate in a culturally unique program. ${ }^{95}$ Spouses and unmarried children under the age of twenty-one can obtain P-4 status, but may not work in the United States. ${ }^{96}$

88. Id. $\S 214.2(\mathrm{f})$.

89. Id. \& $214.2(\mathrm{f})(10)(\mathrm{i})$.

90. Id. $\S 214.2(\mathrm{f})(10)(\mathrm{ii})$.

91. Id. $\$ 214.2(\mathrm{o})(1)(\mathrm{i})$.

92. Id. $\S 214.2(\mathrm{o})(1)(\mathrm{ii})(\mathrm{B})$.

93. Id. $\S 214.2(\mathrm{o})(6)(\mathrm{iv})$.

94. Id. $\$ 214.2(\mathrm{p})$.

95. Id. $\S 214.2(\mathrm{p})(6)(\mathrm{i})(\mathrm{A})-(\mathrm{B})$.

96. Id. § 214.2(p)(8)(iii)(D). 


\section{L. $R$ Status}

The R-1 category is available for certain religious workers, such as ministers and other individuals who will work in a professional religious occupation. ${ }^{97}$ While the individual must be coming to the United States to work in a religious capacity, $\mathbf{R}$ status does not require that the individual have worked in a religious capacity abroad. It simply requires that the person has been a member of the denomination for which he or she will work for at least the past two years. ${ }^{98}$ An individual does not need prior approval from the CIS to apply for an $\mathrm{R}$ visa at a U.S. consular post. Spouses and unmarried children under the age of twenty-one of R-1 status holders may obtain R-2 status.

\section{Effect of Non-Immigrant Overstay or Status Violation}

An individual who remains beyond the period of authorized nonimmigrant stay, works without permission, or otherwise violates the terms and conditions of his or her status can suffer serious consequences. An overstay of even one day renders an individual ineligible for a change of status inside the United States. If the individual applies for and receives a new approval, he or she would be required to depart the United States and apply for a new visa and reentry based on the new status approval. ${ }^{99}$ Additionally, any existing visa would be cancelled, and the overstay or other violation would need to be sufficiently explained to a U.S. consular officer abroad. ${ }^{100}$

Even more significantly, an individual who stays more than six months beyond an authorized stay will invoke a three-year bar on reentry to the United States upon departure. ${ }^{101}$ If the individual overstayed by a year or longer, the bar on reentry raises to ten years. ${ }^{102}$ As non-immigrant change of status cannot be approved within the United States for an individual who is out of status, this reentry bar can be very serious. Criminal activity can also render an individual ineligible for non-immigrant status. ${ }^{103}$

\section{N. Beyond the Non-Immigrant Classifications}

With the limited exception of the $E$ category, non-immigrant classifications each have a maximum time period for which they may be used. After that time, the non-immigrant is expected to depart the United States. For those aliens who wish to remain permanently, the consideration then becomes whether that individual qualifies for any route to lawful permanent residency.

97. Id. $\& 214.2(\mathrm{r})$.

98. 22 C.F.R. $\$ 41.58$.

99. Immigration and Nationality Act $\S 222(\mathrm{~g})(2), 8$ U.S.C. $\S 1202(\mathrm{~g})(2)(2004)$.

100. Id. $\S 222(\mathrm{~g}), 8$ U.S.C. $\S 1202(\mathrm{~g})$.

101. Id. § 212(a)(9)(B)(i)(I); 8 U.S.C. § 1182(a)(9)(B)(i)(I) (2004).

102. Id. $\S 212(\mathrm{a})(9)(\mathrm{B})(\mathrm{i})(\mathrm{II}) ; 8$ U.S.C. $\S 1182(\mathrm{a})(9)(\mathrm{B})(\mathrm{i})(\mathrm{II})$.

103. Id. § 212, 8 U.S.C. $\S 1182$; Id. $\S 237,8$ U.S.C. $\S 1227$ (2004). 
While immigrant classifications are not the topic of this Article, due to the long time periods and qualifying factors involved, non-immigrants who hope to legally remain beyond their eligibility for temporary status must examine carefully the available options. These include family-based options such as those based on a spouse, ${ }^{104}$ fiance, ${ }^{105}$ or immediate family member who is a U.S. citizen. ${ }^{106}$ There are also several employment-based avenues to permanent residence, which include such routes as labor certification (in which an employer demonstrates that there are no available American workers with the needed skill to fill a given position), ${ }^{107}$ multinational manager status, ${ }^{108}$ outstanding professor or researcher status, ${ }^{109}$ and extraordinary ability status. ${ }^{110}$ This is not an exhaustive list of available options, but it provides a sample of potential routes to permanent residence.

Once an individual obtains permanent resident status, he or she can maintain that status indefinitely, or after maintaining such residence for a given period of time, may apply for U.S. citizenship. ${ }^{11}$ Normally, an individual would need to satisfactorily complete five years as a U.S. permanent resident prior to applying for citizenship. ${ }^{12}$ In the case of those persons who obtained permanent residence through marriage to a U.S. citizen, this waiting period is three years. ${ }^{13}$ At least half of the required time as a permanent resident must be spent while physically present in the United States. ${ }^{114}$

\section{STATUS RENEWAL Versus ViSa RENEWAL}

It cannot be stressed enough that status and visa are two separate concepts with very different implications. After successfully obtaining status from the CIS, and possibly a visa from DOS, an individual may have various expiration dates on various documents. This can be due to various reasons, but the important point to always remember is that the status authorizes the individual to remain and possibly to work in the United States, while the visa allows entry into the United States.

When an expiration date on one of these documents approaches, the document must be analyzed for the correct action to be taken: permanent departure from the United States, a request for extension of status from the

104. For K3 Visas, see 8 U.S.C. $\S 1182 \S 101(\mathrm{a})(15)(\mathrm{K})(\mathrm{ii}), 8$ U.S.C. $\S 1101$. For V Visas, see Immigration and Nationality Act $\S 101(a)(15)(V), 8$ U.S.C. $\S 1101$. 1101.

105. For K1 Visas, see Immigration and Nationality Act $\S 101(a)(15)(K)(i), 8$ U.S.C. $\S$

106. Id. $\S 201(\mathrm{~b})(2)(\mathrm{A})(\mathrm{i}), 8$ U.S.C. $\S 1151(2004)$.

107. Id. § $212(\mathrm{a})(5)(\mathrm{A}), 8$ U.S.C. $\S 1182$.

108. Id. $\S 203(\mathrm{~b})(1)(\mathrm{C}), 8$ U.S.C. $\$ 1153(2004)$.

109. Id. § 203(b)(1)(B), 8 U.S.C. $\$ 1153$.

110. Id. $\S 203$ (b)(1)(A), 8 U.S.C. $\S 1153$.

111. Id. $\S 318,8$ U.S.C. $\S 1429$ (2004).

112. 8 C.F.R. $\$ 316.5$ (2004).

113. Id. § 319.1(a)(2) (2004).

114. Immigration and Nationality Act $\S 316,8$ U.S.C. $\S 1427$ (a) (2004). 
CIS, ${ }^{115}$ or application for a new visa from DOS at a U.S. consulate abroad. If the underlying status is expiring, an application for extension may be made to the CIS (in most cases from four to six months in advance) without departing the United States. Evidence of the currently authorized stay is found on the I94 card, which is issued by the CIS for extensions of status and changes of status within the United States, or by the CBP upon entry into the United States. ${ }^{116}$

If the visa is expiring but the underlying existing, extended, or changed status will remain valid, no action needs to be taken unless travel out of, and return to, the United States is contemplated, because a visa is used only for entry purposes. When a visa is expiring, application for a new visa can be made at a U.S. consulate abroad as early as sixty days prior to expiration of the current visa. However, if an individual has changed to a new status classification, he or she may apply for a visa in the new classification at any time.

\section{VISA RENEWAL ISSUES}

Foreign nationals legally working in the United States and their U.S. employers often find themselves in a difficult and unnecessary position. These individuals, most often professionals contributing to the U.S. economy, are normally able to receive extensions of permission from CIS to remain in the country and continue working in legitimate and valuable occupations for a limited period of time.

A difficulty arises for these employees and their U.S. employers in that the employees often need to travel internationally for both business and personal reasons. In most cases, this requires the additional step of obtaining a visa from the DOS in addition to the legal status already granted by the CIS.

This process often involves significant business interruption for the employer, personal difficulties for the employee, and great monetary expense for both. This inconvenience also applies to individuals who have changed status with approval from the CIS. For example, a student hired after completing a U.S. university degree, and approved for a professional status by the CIS while still present, would need a visa in a new classification in order to travel outside the United States. Until recently, most visa-seekers already in the United States had three main options: travel to a U.S. Consulate in Canada or Mexico, travel to a U.S. Consulate in the employee's home country, ${ }^{117}$ or revalidate by mail from within the United States. ${ }^{118}$ As explained below, this third option no longer exists.

115. See 8 C.F.R. $\$ 214.1$.

116. Id. $\S \S 235.1(\mathrm{f}), 235.4$ (2004).

117. 22 C.F.R. $\S 41.101$ (a).

118. U. S. DEPARTMENT OF State, 9 Foreign AFFairs MANual, Visas 41.102 (2003), http://foia.state.gov/masterdocs/09fam/0941102R.pdf (last visited Feb. 7, 2005). 
The issuance of these visas is critical to the U.S. economy. All three previously existing methods were useful, but only because a better system has not been designed. All three are wasteful and time-consuming for employees, employers, and U.S. taxpayers. ${ }^{119}$

Sending employees to consulates in Canada or Mexico presents several problematic issues, several of which negatively impact the U.S. economy. The most immediate impact is the cost and loss of valuable work time from the employee. The costs of sending an employee to Canada or Mexico normally include airfare, lodging and other associated expenses. These costs increase quickly as family members are added to the travel expenses. Additionally, since the consulates do not operate on weekends or holidays, an employee must normally miss a minimum of two workdays. Recent changes expanding interviews as well as security and name checks may push this number up to several days. Many nationalities also require a Canadian or Mexican visitor visa in order to travel to the U.S. consulate, increasing cost and delay even further.

Similarly, employees who travel to a U.S. Consulate in their home country often experience large, unnecessary costs, and even longer delays waiting for a visa interview. This process results not only in time lost to U.S. companies, but a massive amount of money spent on airfare, lodging, entertainment, cabs, restaurants, and other items in foreign countries that could have been spent in the United States, or returned to the company bottom line. Hundreds of appointments are made at U.S. Consulates in Canada each week. ${ }^{120}$ These appointments result in millions of dollars pouring into Canada that should be spent in the United States. The same is true of appointments in Mexico and employees' home countries. This volume of legitimate individuals traveling abroad for the purpose of obtaining new visas to carry out their duties (remember, the visa is only needed for travel, and in most cases these individuals have already received approval to remain in the U.S.) also unnecessarily adds volume to the border and customs officers who review these individuals upon their return from abroad.

The process of requiring or providing strong incentives to already-vetted and approved individuals to travel out of the United States in order to obtain

119. Two other alternatives have been proposed: use of existing CIS biometric data collection offices to verify an applicant's identity, or extension of automatic visa revalidation to cover all travel. Letter from Advantest America Co., et. al., to Colin Powell, U.S. Secretary of State, and Tom Ridge, Secretary of U.S. Homeland Security, (July 12, 2004), at http://www.aila.org/newsVieweraspx?bc=273\&docID $=13570$ (last visited Feb. 7, 2005). However, the former option may not allow for sufficient security checks while the person is available to be taken into custody (including added need for security and CIS officers at each of the biometric data collection points) and would be extremely difficult to match up with processing by mail. The latter option provides no security or identity evaluation, and would create additional confusion and need for secondary inspection at CBP processing posts.

120. See generally U.S. Dept. of State, Visa Appointment Reservation System, at www.nvars.com (last visited Feb. 1, 2005). 
travel visas is, in fact, an outsourcing of potential growth for the American economy. For example, without the visa revalidation option below, a Japanese executive whose U.S. operation employs hundreds of U.S. workers could be forced to travel to Japan and spend three to five weeks or more waiting for a travel visa, even after waiting to obtain an interview. ${ }^{121}$ This unnecessary time away from work (the individual's status and work permission have already been granted by CIS in most cases) could jeopardize the U.S. operation and its U.S. workers.

The third option previously available for some individuals had been the revalidation of existing visas by mail through DOS in Washington, D.C. This process was limited to people holding, or who very recently held, the same classification of visa they wished to renew. It was not available to individuals applying for the first time in the requested classification.

Unfortunately, this process often took ten to sixteen weeks or longer, during which time the applicants were without passports and original CIS authorizations. Some practitioners even reported lost, delayed and, misdirected original documents, as well as incorrect processing. This revalidation-by-mail process was eliminated on July 16,2004 , due to the fact that these visa issuances did not involve in-person verification of identity. ${ }^{122}$ While creating serious problems for some, this step was understandable in the post-9/11 security environment because the DOS must be sure that the individual receiving a visa is actually the person represented by the paperwork presented.

\section{A PROPOSAL FOR RENEWAL}

In order to address the security, identity, and economic issues involved in visa revalidation, a new domestic DOS post to conduct in-person visa processing should be created. A central facility could be established in a U.S. city, possibly in an economically blighted area, to spur jobs and redevelopment, or perhaps in the planned build-out space at the CIS National Benefits Center (formerly and briefly known as the Missouri Service Center), to process visas only for persons currently legally in the United States and with prior approval and authorization from CIS.

While unconventional, this action would have multiple beneficial effects. Millions of dollars now spent in Canada, Mexico and other countries would instead flow to domestic airlines, hotels, restaurants and cab drivers as the applicants travel to a U.S. city and wait there for visa issuance. Security concerns with the current revalidation-by-mail process would be eliminated because each applicant and family member would be subjected to in-person interviews and biometric data collection. Applicants could also be asked to

121. See generally U.S. Dept. of State, Visa Wait Times, at http://travel.state.gov/visa/ tempvisitors_wait.php. (last visited Feb. 1, 2005).

122. Discontinuation of Reissuance of Certain Nonimmigrant Visas in the United States, 69 Fed. Reg. 35,121 (Jun. 23, 2004). 
validate information provided to CIS with employment and domicile documentation.

One justification for requiring some applicants to apply abroad may be that if the applicant is denied, they become the problem of the local government and do not require removal or Immigration Court proceedings. However, the vast majority of these applicants are legitimate professionals, all of whom have already been vetted by the CIS. The processing center could also take into custody any individual determined to be a security or criminal threat. If removal should become an issue for a significant number of applicants, DOS could require the posting of a bond for the purpose of covering return airfare when required, but in any case if the individual applying is one who should be removed, this proposed system would result in removal rather than continued presence in the United States.

With a domestic processing facility, the individuals would actually have to present themselves for investigation, fingerprinting, photographing, and a background check, which could result in a person being taken into custody if deemed a threat. The justification for sending these individuals abroad is the antiquated desire to have a non-admissible person be outside the United States at application so that deportation would not be necessary. The proposed system would be more appropriate in the current heightened security environment.

This system would also reduce the number of work days lost in many cases, reduce total dollar expense to the employee and employer, and reduce the burden on border officers. In addition, the new post could provide costeffective training for, and probationary review of, new consular officers without first relocating them abroad. It would also add a large number of jobs for U.S. workers employed at the post (direct), and for an even larger number in support services (indirect). The center could even be intentionally located in an economically-blighted area to turn around a local economy. In fact, a modest "premium" fee could be charged to applicants to assist in covering start-up costs for the facility.

The establishment of this facility would provide increased security, efficiency, and jobs for American taxpayers. It would also provide increased efficiency and lower costs for U.S. companies and critical employees of these operations. The facility would also energize a local economy, and provide a cost-effective, real world training ground for new State Department visa officers without the need to first locate them overseas.

\section{CONCLUSION}

Many measures taken in response to $9 / 11$ were necessary to help ensure the safety of Americans at home and abroad, and were well justified. However, many of these measures are also costly and time consuming. A new domestic revalidation facility would benefit the individuals involved, as well as the economy - both local and national—while providing training opportunities for DOS and immigration officials, and allowing additional opportunities to verify identities and apprehend any discovered status violators or criminal aliens. 
In most cases, the alien has already been authorized to remain and possibly to work in the United States, and a visa is only needed for returning to the United States after travel abroad. As such, the distinction between status and visa is an important one. Ultimately, many types of non-immigrant status exist, and the determination that a given position or potential employee may qualify for a given non-immigrant status requires analysis by an individual with detailed and current knowledge of the requirements of each potential category, as well as the potential effects that given actions, or inaction, can have on future non-immigrant or immigrant applications. 
